\title{
The Influence of Room Prices and Promotion Costs on Hotel Room Occupancy Rates in Palopo City, South Sulawesi
}

\author{
Wayan Suardana ${ }^{1}$, Muhadjir Suni' ${ }^{2}$, Masri Ridwan ${ }^{3}$ \\ ${ }^{1,2,3}$ Poltekpar Pariwisata Makassar \\ E-mail: ${ }^{1}$ wsuardana900@ gmail.com, ${ }^{2}$ muhadjirsuni@yahoo.com, \\ 3. masriridwan@poltekparmakassar.ac.id
}

\begin{abstract}
Hotel competition in South Sulawesi Province in 2018 has increased. This study aims to: determine the price of hotel rooms in the city of Palopo, South Sulawesi Province, find out how the cost of hotel promotions in the City of Palopo, South Sulawesi Province, find out whether the room price and promotion costs have a significantly positive effect on hotel room occupancy rates in Palopo City, South Sulawesi Province. This type of research is descriptive quantitative research. Data collection techniques used are the method of observation, documentation techniques and questionnaires. The results showed that of 17 Hotels / Pensions / Villas in Palopo City, South Sulawesi Province, the room occupancy rate was on average $27 \%$. Promotion fee is Rp. 17,368, - per room. Of the two regression coefficients possessed by the two independent variables, the two independent variables (X1) namely room price and promotion costs (X2) have a significant positive effect on the occupancy rate of the room (Y).
\end{abstract}

Keywords: Room Rates, Promotion Fees, Room Occupancy Rate

\section{INTRODUCTION}

The hotel industry plays a very important role. The hospitality industry has a significant influence not only on tourism competitiveness but also on general development in an area of a city or country (Attila, 2016). In Indonesia, industrial competition is not much different from the conditions in various countries in the world. In 2018 the competition in the hotel industry increased, especially in the area of South Sulawesi Province. The Central Bank of the Republic of Indonesia in the South Sulawesi Province Economic Report 2019 stated that $2.98 \%$ of inflation pressure eased compared to the previous quarter of $3.08 \%$. Characterized by the growth of hotel rooms that are experiencing very rapid development. The price of hotel needs has also increased, while room occupancy tends to decrease due to the mushrooming growth of hotels in South Sulawesi.

The Indonesian economy has recorded strong growth over the past few decades (Niswaty, Juniati, Darwis, Salam, \& Arhas, 2019). In recent years the pace of economic expansion has been accompanied by a steady decline in output volatility and relatively stable inflation (Elias \& Noone, 2011). The decline in world economic growth also impacts on the decline in economic growth in Indonesia, one of which is that many companies were once successful, ultimately due to global competition. Tempo Magazine reported that the list of companies that went bankrupt in the South Sulawesi region included PT Sunjin Industries Indonesia (leather factory), PT Taisui (wood factory), and PT Citar Sekar Wangi (cashew processing factory). The companies 


\section{Jurnal Administrare: Jurnal Pemikiran Ilmiah dan Pendidikan Administrasi Perkantoran Volume 6 Number 2 July- December 2019. Pages 123-130}

that changed production include PT Bosowa Plastindo Perkasa, PT Polywood Forest Industries and PT Rotan Sulawesi. One industry that has the potential to close down is the industry in the hotel sector. The contributing factor is the amount of growth in the hotel sector, this phenomenon has an impact on declining room occupancy rates, while tourists or business activities have not experienced a significant increase in South Sulawesi. Thus, hotel leaders are required to always follow economic trends.

The Presidential Election on April 17, 2019, investors are still waiting for the results, who will lead the Indonesian people going forward and what political policies are implemented for the sake of increasing economic growth. Room occupancy rates also take part in economic growth, in Indonesia in general, in Sulawesi in particular, will have an impact on the decline in room occupancy rates so that they can understand the situation and respond to events that affect the conditions of companies in the hotel sector.

One of the effects of an unstable economic situation is the decline in the value of the rupiah against foreign currencies, inflation that tends to increase, interest rates are still high, a decline in economic conditions that have an impact on decreasing tourist trips both foreign and domestic tourists are very closely related to the means accommodations like hotel. The higher level of travel both in the form of business and tourism interests also determines hotel occupancy rates. The number of tourists has a positive and significant effect on the Local Revenue. (Riri, 2014)suggested that the number of tourists had a positive effect on hotel occupancy in the city of Padang with a coefficient value of 0.399 , this coefficient value was significant because t-counts were large from t-tables. While Supriyanto's research (2017) says that the number of tourists has a positive and significant influence on hotel tax revenues in the city of Makassar. In the study, the results of the path analysis showed that there were indirect and direct effects of the number of tourists on hotel tax revenue with GRDP as an intervening variable.

The Chairman of South Sulawesi Province PHRI, Agiat Sinaga said: "The occupancy rate of hotel rooms has tended to show that the graph has declined in the last three years". In South Sulawesi there are around 13,350 hotel rooms with occupancy rates in 2017 an average of 58\%. The number of Hotels in South Sulawesi is about 265 hotels consisting of 158-star hotels and the rest are non-star hotels. Chairman of PHRI South Sulawesi). To increase the room occupancy rate, one of them is a promotion from both the government and the hotel itself.

One of the potential areas for the development of the hotel industry in South Sulawesi is in the City of Palopo. This potential is supported by the existence of Palopo City as the economic center of the northern region of South Sulawesi. Its position is at the gateway of sea transportation as the largest port after the Ports of Makassar City and Pare-Pare. Palopo's orientation as an economic center can support the MICE Industry. This was confirmed by (Ummi \& Marwan, 2013) suggesting that Palopo City has a spatial structure policy that embodies an activity center that strengthens agro-industry, trade and service activities as well as tourism and other city activities optimally.

Palopo City which has been equipped with Lagaligo Airport in Bua has a great opportunity as an alternative location for tourists who will visit Tana Toraja as a tourist transit location. Thus, this opportunity can contribute to the level of room occupancy (one night stay) before tourists continue their journey to the main destinations in North Toraja and Tana Toraja Regencies. 
However, the problems that occurred in Palopo City, particularly in the hotel sector, were identified as follows: 1) The marketing strategy brought with it the consequence of the declining quality and marketing strategy of the service business, 2) The decreasing level of demand for accommodation services managed by the hospitality business. Based on the identification of these problems, it can be said that the sluggish hospitality business as a result of inadequate marketing strategies that are appropriate, thus affecting the sales of the room occupancy rate. Baharman Supri and Rudianto's research (2017) strengthens the evidence that the Role of Hotel Taxes in the City of Palopo Against Economic Growth over the past five years (2013-2017) has fluctuated with each value being $123.13 \% ; 105.51 \%$; $113.30 \% ; 121.21 \%$; and $74.47 \%$ while the hotel tax realization for the last five years $(2013-2017)$ tended to decrease respectively by $7.86 \% ; 7.82 \% ; 7.84 \% ; 7.90 \%$; and $7.84 \%$.

A series of efforts have been made by the local government and hotel management in Palopo City, one of which is marketing, both domestically and abroad in accordance with their competencies, improving employee welfare in the form of facilities and funds owned, but the low occupancy rate of hotel rooms in Palopo City. South Sulawesi Province.

\section{METHOD}

This type of research is descriptive quantitative research. (Sugiyono, 2012) suggested that descriptive quantitative research as a research method based on the philosophy of positivism. The location of the study was in hotels in Palopo City, South Sulawesi Province. Data on room rates, promotion costs, and occupancy rates will be obtained through direct interviews with hotel employees, as well as questionnaires. Data Collection Techniques used in this study were collected using several techniques, namely: observation method, namely by conducting a direct review of the activities of hotels in Palopo City, South Sulawesi Province; documentation techniques, data collection is done through available documentation at hotels in Palopo City, South Sulawesi Province; the questionnaire, which distributes questionnaires to employees of the Front Office Section of hotels in Palopo City, South Sulawesi Province. Data analysis of the two independent variables (X1) namely room prices and promotion costs (X2) have a significant positive effect on room occupancy rates.

To analyze data on room prices in Palopo City of South Sulawesi Province, to analyze data on promotion costs Management of Palopo City Hotels in South Sulawesi Province, while to analyze data on the influence of room prices and promotion costs on room occupancy rates analyzed Statistically, the multiple regression model with the equation in the form of logarithms is as follows:

$\ln \mathrm{Yi}=\ln \mathrm{X}_{1} \mathrm{i}+\mathrm{B}_{2} \ln \mathrm{X}_{2} \mathrm{i}+\mathrm{Ei}$

$(i=1 \ldots, n)($ Gujarati \& Porter, 2009)

is:

Ln $1,2,3=$ Nonlinear regression coefficient

0 Constant

With 2 independent variables, namely::

$\mathrm{X}_{1} \quad=\quad$ Room price

$\mathrm{X}_{2} \quad=\quad$ Promotion fee

Dependent variable: 
126 Jurnal Administrare: Jurnal Pemikiran Ilmiah dan Pendidikan Administrasi Perkantoran Volume 6 Number 2 July- December 2019. Pages 123-130

$\mathrm{Y} \quad=\quad$ Room occupancy

$\mathrm{E} \quad=\quad$ Dumming variabel

Furthermore, several statistical tests will be performed to test the hypothesis raised, including t-test, $\mathrm{F}$ test, and calculating $\mathrm{R}$, and $\mathrm{R}^{2}$.

\section{RESULT AND DISCUSSION}

In this section the results of the study and discussion are as follows:

\section{Description of Each Variable}

Table 1. Room Prices and Hotel Promotion Costs in Palopo City, South Sulawsi Province

\begin{tabular}{clccc}
\hline No. & Hotel Names in Palopo City & $\begin{array}{c}\text { Room Occupancy } \\
\text { Rate } \\
(\mathrm{Y})\end{array}$ & $\begin{array}{c}\text { Room / Night } \\
\text { Price } \\
(\mathrm{X} .1)\end{array}$ & $\begin{array}{c}\text { Promotion / } \\
\text { Room Fee } \\
(\mathrm{X} .2)\end{array}$ \\
\hline 1 & Hotel Rioriata & 20 & $250.000,00$ & $12.500,00$ \\
2 & Hotel Yasmin & 25 & $300.000,00$ & $15.000,00$ \\
3 & Hotel Grand Illa & 41 & $275.000,00$ & $15.000,00$ \\
4 & Hotel Primer & 25 & $200.000,00$ & $10.000,00$ \\
5 & Hotel Awana & 18 & $250.000,00$ & $12.500,00$ \\
6 & Hotel Risma & 38 & $250.000,00$ & $12.500,00$ \\
7 & Hotel Buana & 38 & $150.000,00$ & $7.500,00$ \\
8 & Hotel Horas & 36 & $225.000,00$ & $11.500,00$ \\
9 & Kambo Higland Park Villa \& Resto & 5 & $1.350 .000,00$ & $67.500,00$ \\
10 & Hotel Value & 75 & $350.000,00$ & $17.500,00$ \\
11 & Latuppa Wisata Agro Hotel \& Resto & 14 & $500.000,00$ & $25.000,00$ \\
12 & D' Mario New Hotel & 13 & $250.000,00$ & $12.500,00$ \\
13 & Platinum Hotel & 32 & $500.000,00$ & $25.000,00$ \\
14 & Hotel Warna & 39 & $175.000,00$ & $8.750,00$ \\
15 & Hotel Mulia Indah & 4 & $300.000,00$ & $15.000,00$ \\
16 & New Hotel Palopo & 5 & $300.000,00$ & $15.000,00$ \\
17 & Hotel Harapan & 32 & $250.000,00$ & $12.500,00$ \\
\hline Average & 27 & $345.588,00$ & $17.368,00$ \\
\hline Source: researcher primary data & & &
\end{tabular}

The Average Room Prices, Promotional Costs, Hotel Room Occupancy Rates from January to June 2019 in the city of Palopo, South Sulawesi Province can be seen in Table 2: 
Table 2. Average: Room Rates, Promotional Costs, Hotel Room Occupancy from January to June 2019 in the city of Palopo, South Sulawesi Province

\begin{tabular}{cccccccc}
\hline No & \multicolumn{1}{c}{ Keterangan } & Jan 2019 & Feb 2019 & Mar 2019 & Apl 2019 & May 2019 & Jun 2019 \\
\hline 1 & $\begin{array}{l}\text { Average Room Prices } \\
\text { /night (Rp) }\end{array}$ & 345.588 & 345.588 & 345.588 & 345.588 & 345.588 & 345.588 \\
\hline 2 & $\begin{array}{l}\text { Average promotion / } \\
\text { room fee (Rp) }\end{array}$ & 17.368 & 17.368 & 17.368 & 17.368 & 17.368 & 17.368 \\
\hline 3 & $\begin{array}{l}\text { The occupancy rate } \\
(\%)\end{array}$ & 27 & 27 & 27 & 27 & 27 & 27 \\
\hline
\end{tabular}

Source: researcher primary data

As for the room price, promotion costs and occupancy rates of the Cobb-Douglas room, you can see the following Table 3 below:

Table 3. Room Prices, Promotional Costs, and Room Occupancy Rates with (Cobb-Douglas Model) Room Prices, Promotional Costs, and Room Occupancy Rates with (CobbDouglas Models)

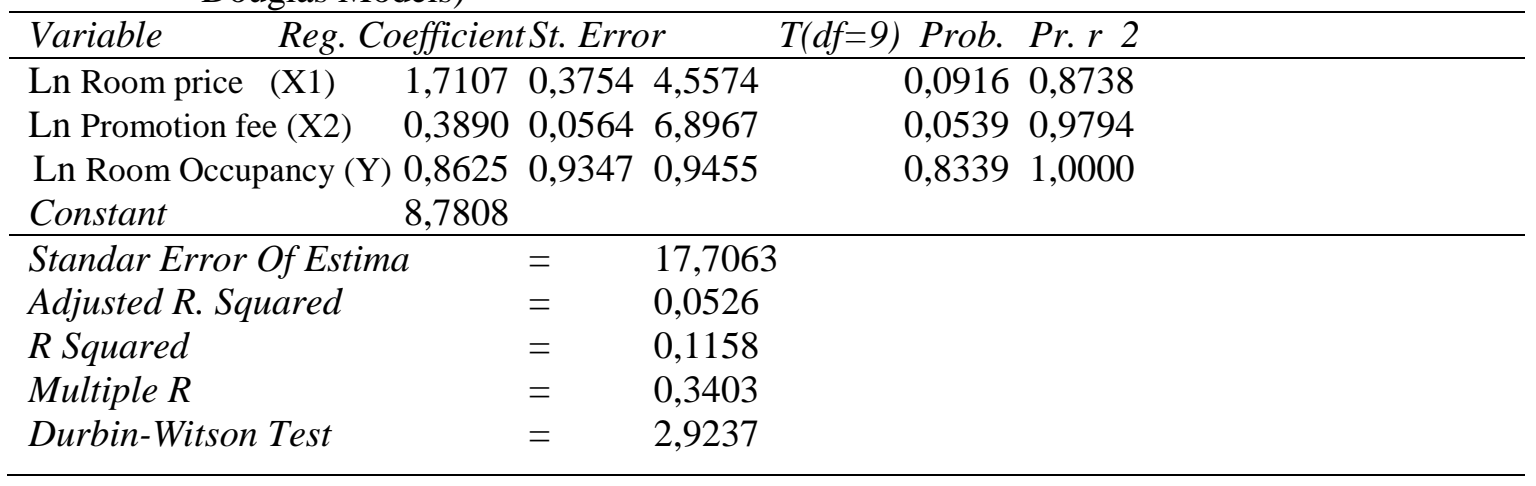

The estimated room prices, promotional costs, and room occupancy rates can be seen in Table 4 below:

Table 4. Estimated Room Prices and Promotional Costs at Hotels in Palopo City, South Sulawesi Province (Cobb-Douglas Model)

\begin{tabular}{|c|c|c|c|c|c|c|}
\hline Variable & Reg. $C$ & oefficient & tSt. Error & ) & Prob. & Pr.r 2 \\
\hline Ln Room price (X1) & 0,3883 & 0,1338 & 2,902 & 0,0181 & 0,8938 & \\
\hline Ln Promotion fee (X2) & 0,3890 & 0,0564 & 6,896 & 0,0539 & 0,9794 & \\
\hline Ln Room Occupancy (Y) & 0,8625 & 0,9347 & 0,9455 & 0,8339 & 1,0000 & \\
\hline Constant & 0,7808 & & & & & \\
\hline \multicolumn{2}{|c|}{ Standar Error Of Estimasi } & $=$ & 17,7063 & & & \\
\hline \multicolumn{2}{|c|}{ Adjusted R. Squared } & $=$ & 0,0526 & & & \\
\hline \multicolumn{2}{|l|}{$R$ Squared } & $=$ & 0,1158 & & & \\
\hline \multicolumn{2}{|l|}{ Multiple $R$} & $=$ & 0,3403 & & & \\
\hline \multicolumn{2}{|l|}{ Durbin-Witson Test } & $=$ & 2,9237 & & & \\
\hline
\end{tabular}




\section{Jurnal Administrare: Jurnal Pemikiran Ilmiah dan Pendidikan Administrasi Perkantoran} Volume 6 Number 2 July- December 2019. Pages 123-130

Based on Table 4 Cobb-Douglas nonlinear regression can be arranged as follows:

$$
\mathrm{Y}=\mathrm{Ln}_{0} \mathrm{X}_{1}{ }^{\mathrm{Ln} 1} \mathrm{X}_{2}{ }^{\mathrm{Ln} 2}
$$

Substituted as:

$$
\begin{array}{ll}
\mathrm{Y} & =0,7808 \mathrm{X}_{1}^{0,3883} \mathrm{X}_{2}, 3890 \\
\text { or: } & \\
\text { Ln Y } & =0,7808+0,3883 \operatorname{Ln} \mathrm{X}_{1}+0,3890 \operatorname{Ln} \mathrm{X}_{2}
\end{array}
$$

Regression results indicate the direction of the influence of independent variables on the dependent variable determined by the regression of each independent variable. Overall independent variables, namely: room rates, and promotional costs, have a significant positive effect on room occupancy rates.

Furthermore, to find out the existence of each independent variable to the dependent variable, a t-test was used. T-test results for each regression coefficient can be seen in Table 4: Regression coefficient (X1) 0.3883 has t-count 4.890 while t-table 2.350 at a $5 \%$ confidence level, meaning t-count is greater than t-table with a probability of 0.21127 which means the room price variable (X1) has a significant effect positive on room occupancy rate variable (Y); Regression coefficient (X2) 0.3890 has t-count of 4.891 while t-table of 2.35 at a $5 \%$ confidence level, means $\mathrm{t}$-count is greater than $\mathrm{t}$-tables with a probability of 0.0916 which means the variable promotion costs (X2) significant positive effect on the room occupancy rate variable (Y).

\section{Regression Coefficient}

From the regression coefficients listed in Table 4, it can be described as follows:

$\operatorname{Ln}_{1}=0,3883$

This means, any decrease in the room price (X1) by $10 \%$ will affect the increase in room occupancy (Y) by 0.3883 or 38.83 percent. Initially the average room price of Rp. 345,588, - if lowered by $10 \%$ the room price will be Rp. 345,588 (5\% X Rp. 345,588) is Rp. 311,029, - every room sold. The average room occupancy rate in 2019 is $27 \%$, if the room price in the coming period is reduced to $10 \%$ of the original room price, it will affect the room occupancy rate from $27 \%$, to $27 \%+(27 \% \mathrm{X} 0.3883)$ is $37.48 \%$. So in 2019 in the coming year, the room occupancy rate from $37.48 \%$ will be $37.48 \%$ in the following years.

$\operatorname{Ln}_{2}=0,3890$

This means, each increase in promotion costs $100 \%$ of the promotion cost 1 room price will affect the increase in room occupancy $(\mathrm{Y})$ by 0.3890 is $(38.90 \%) \mathrm{X}$ room price, or every increase in promotion fee by $100 \%$ per room, it will affect the increase in room occupancy by $38.90 \%$. In table 2 the average room occupancy rate in 2019 is $27 \%$ if the initial promotion cost is Rp. 17,368.00 - (Rp. 17,368.00 X 38.90\% (if raised) = Rp. 6,756, - promotional costs to Rp. Initially $=27 \%+(27 \% \times 38.90 \%)=37 \%$ So each increase in promotion costs is IDR 6,756 , each promotional cost incurred will affect the occupancy rate of the room $37.50 \%$, of the two regression coefficients owned by the two independent variables, the two independent variables 
(X1) namely room prices and promotion costs (X2) have a significant positive effect on room occupancy rates. This finding complements the previous research (Djuarsa, 2009) that there is a significant relationship between the promotional costs budget the level of occupancy or budget promotion costs conducted by the company will affect the occupancy rate of the company (Case study at the Grand Serela Hotel Bandung), while research (Saleem, 2013) found that hotel characteristics, internal factors and external factors have an impact on occupancy rates in Amman. Hotel characteristics (hotel location, size, number of rooms) have an impact on Jordan's hotel occupancy rates. Furthermore, the study explained that internal hotel factors including: service quality, room facilities, prices, employee attitudes, and cleanliness have an impact on hotel occupancy rates in Jordan and hotel external factors include: economic status, exchange rates, political situation and intensive competition impact on Jordan hotel occupancy rates.

\section{CONCLUSION}

The Room / Hotel / Villa Room Occupancy Rate in Palopo City, South Sulawesi Province, in 2019 an average of $27 \%$. The cost of promoting hotels in Palopo City ranges from Rp. 17,368, - every room sold. From the two regression coefficients possessed by the two independent variables, the independent variable (X1), namely room price and promotion cost (X2) has a significant positive effect on room occupancy rates.

\section{REFERENCES}

Attila, A. T. (2016). The Impact of the Hotel Industry on the Competitiveness of Tourism Destinations in Hungary. Journal of Competitiveness. https://doi.org/10.7441/joc.2016.04.06

Djuarsa, S. M. (2009). Pengaruh Anggaran Biaya Promosi Terhadap Tingkat Hunian Hotel (Studi kasus pada Hotel Grand Serela Bandung). Universitas Widyatama.

Elias, S., \& Noone, C. (2011). The Growth and Development of the Indonesian Economy. Reserve Bank of Australia.

Gujarati, D. N., \& Porter, D. C. (2009). Basic of Econometric, Fifth Edition. In Econometrics. https://doi.org/10.1007/978-1-137-37502-5_17

Niswaty, R., Juniati, F., Darwis, M., Salam, R., \& Arhas, S. H. (2019). The Effectiveness of Leadership Functions Implementation in The Makassar Departement of Manpower. JPBM (Jurnal Pendidikan Bisnis dan Manajemen), 5(1), 1-10.

Riri, Y. S. (2014). Pengaruh Tingkat Hunian Hotel, Jumlah Wisatawan, Dan Jumlah Objek Wisata Terhadap Pendapatan Asli Daerah (Pad) Kota Padang Tahun 2003-2012. Pendidikan Ekonomi: Sekolah Tinggi Keguruan Dan Ilmu Pendidikan (STKIP) PGRI.

Saleem, A. S. M. R. Al. (2013). Factors Affecting Hotels Occupancy Rate (An Empirical Study 
130| Jurnal Administrare: Jurnal Pemikiran Ilmiah dan Pendidikan Administrasi Perkantoran Volume 6 Number 2 July- December 2019. Pages 123-130

on Some Hotels in Amman. Interdisciplinary Journal of Contemporary Research in Business, 5(6).

Sugiyono. (2012). Metode Penelitian Kuantitatif, Kualitatif dan R \& D.Bandung:Alfabeta. Metode Penelitian Kuantitatif, Kualitatif dan $R \quad \& \quad$ D.Bandung:Alfabeta. https://doi.org/10.1017/CBO9781107415324.004

Ummi, M., \& Marwan. (2013). Kajian Strategi Pengembangan Industri Pengolahan Ikan Di Kota Palopo Provinsi Sulawesi Selatan. Jurnal Teknologi Perikanan dan Kelautan., 4(2), 197-209. 